\title{
The Role of E-Government In Fighting Against The Corruption: A Case Study Of Vietnam
}

\author{
Pham Thanh Nga \\ Hanoi Department of Justice, 221 Tran Phu street, Ha Dong district, Hanoi 10000, Vietnam
}

\begin{abstract}
Corruption is always a big problem exist in every country. Today, the corruption is not only in the public sector but also in the private sector. Each State has used many ways to prevent and fight this crime. The 4th Industrial Revolution (4IE) brings many innovative solutions for modern life. Especially, e-Government is a great achievement of the 4IE. Base on the e-Government, the policies and regulations of States are transparent. It plays an important role to prevent and fight corruption more effectively. In this paper, the author will analyze the case study of Vietnam on fighting corruption base on the information technology and the outcome of applying e-Government on preventing and fighting corruption in both public sector and private sector. From this result of research, the author will recommend some solutions to improve the corruption status in Vietnam on the next period.
\end{abstract}

Keywords: e-government; corruption; role; fighting; Vietnam.

\section{Introduction}

Information and communication technologies (ICT) were the trigger factors for the economic, political and social changes since the invention of the digital computer (mid-1940s), which were accelerated with the advent of the Internet (the early '90s). Currently, the work of public institutions depends increasingly more on the technical and architectural choices that are made at the level of technology. Most of the principles of good governance are expressed in the roles of e-government; in other words, focus on transparency, openness, citizen participation, effectiveness, efficiency, accountability, etc. The information technologies are important for direct accountability: citizens can have direct access to information about the functioning of public institutions and use communication technologies for public debates (Northrup and Thorson, 2003). Northrup and Thorson (2003) argue that this form of accountability requires transparency and reduces corruption. E-government refers to the use of information and communication technologies by government agencies to transform relations with citizens (G2C), businesses (G2B) and government organizations (G2G). Information technologies have a variety of ends: improving service delivery to citizens, interaction with business and industry, increase public accessibility to information, more efficient government management, and eventually reduce corruption, increase transparency and reduce costs. ICT offers a new approach to create transparency and promote anti-corruption, leading to improved transparency and accountability in the functioning of public organizations and allowing government to expand its role as a provider of services focused on customers, which is the essence of development activities for e-government.

Overall, corruption in Vietnam is characterized by a weak legal infrastructure, financial unpredictability, and conflicting and negative bureaucratic decision-making. Surveys reveal that petty corruption has decreased significantly throughout the country, while high-level corruption has increased. Corruption is considered an obstacle for doing business in Vietnam, and the use of facilitation payments are widespread when dealing with frontline civil servants. Corruption has moved up the political agenda in Vietnam, and the legal framework for tackling corruption is

\footnotetext{
* Corresponding author.

E-mail address: pham.nga.hlu@gmail.com (Pham Thanh Nga)
} 
now better developed. Transparency International's 2017 Corruption Perception Index ranks the country 107th place out of 180 countries. But recent years, with apply achievement of 4th IE, Vietnam's corruption has decreased. Following the statistic of transparency organization, Vietnam ranks at 96 place out of 180 countries, decrease 11 steps in compare with in 2017. From this rank, we can see that e-government has given a positive impact on decreasing corruption in Vietnam.

In this paperwork, the author will also analyze the relationship between e-government and corruption, then give the conclusion and recommendation at the end.

\section{Literature review}

Do Lap Hien (2017), "E-Government Policy of Vietnam", 3rd Asia-Pacific Regional Forums on Smart Cities and eGovernment 2017: According to the United Nations' assessment of e-government in August 2016, Vietnam ranks 89th place out of 193 countries. With this result, Vietnam has risen 10 steps compared with 2014 survey results. Most government agencies have $100 \%$ employees using email to work. Most government agencies have document management system. But, the rate of e-document exchange is low (about $30-40 \%$ ). Some other system is efficiently implemented such as budget management system, financing and accounting system, human resources management system, etc.

The relationship between e-governance and corruption has been analyzed by several authors (Anderson, 2009; Shim \& Eom, 2008; Mauro, 1997 Martha and Ortega, 2010), but Mistry and Jalal (2012) were the first to establish causality for this important relationship. The results of their study suggest that the use of ICT in e-governance leads to lower corruption. The authors, in their analysis carried out during 2003-2010, have also found that the impact of egovernment is higher in developing countries than in developed countries. Martha and Ortega (2010) use in their analysis a corruption model developed by Klitgaard in his study, which includes the factors: number of internet portals of government, monopoly power of the government, discretion of public servants and responsibility of bureaucracy. Using a period of six years (2002-2005 and 2008) for 187 countries and panel data analysis as methodology, they found that electronic government initiatives have reduced corruption worldwide. The authors recommend that international agencies support and promote electronic government projects, in addition to other anticorruption measures. E-governance may successfully control some corrupt practices, but may also lead to the emergence of new ones. Corrupt practices can migrate from one place to another and new actors can enter power structures and influence systems for their own benefit. In the case of Bangladesh Railway, e-governance reduced opportunities for corruption but also introduced new actors from outside the existing system. Under the earlier paper ticketing system, officials had discretion which was lost with the introduction of online ticketing. Now, however, people can buy tickets online and sell them on at higher prices. This illegal practice occurs both with and without collaboration from officials. Ordinary travelers continue to suffer from higher-than-necessary ticket prices as a result. The effectiveness of e-governance varies according to its type and the nature of corruption. All types of e-governance are not a panacea for all types of corruption. The cases described above suggest certain types of e-governance are more effective in dealing with petty corruption involving street-level bureaucrats than in dealing with grand corruption involving higher level officials. This is because e-governance can change the nature of public service delivery so as to reduce or entirely eliminate the necessity for citizen interactions with petty officials. This feature of e-governance does not, however, affect corrupt practices at a policy or strategic level, which may continue unabated. If a higher level authority tailors a certain policy to unduly favor a particular interest group, e-governance is unlikely to positively affect such outcomes given that it will itself be dependent on the same policy inputs. The Bangladesh Railway is a case in point: there are strong allegations that tendering conditions for outsourcing the e-ticketing system were set in such a way as to create favorable conditions for a specific company.

Ganuza \& Hauk (2004) studied the link between corruption and economic integration based on common procurement rules, and demonstrated that even if national governments in countries that enter into an economic union are corrupt, the positive perception of citizens about the benefits of integration economic and political, will eventually lead to the 
reduction of national corruption. Between the countries that joined the EU and those not accessing exists a significant difference in reducing corruption by using e-government. In addition to the above variables, we use a number of control variables to track the impact of corruption in the regression models used. Specifically, we use the following indicators specified as having impact in the specialty literature..

\title{
3. Methodology
}

To make this research in this paper, the author investigated whether changes in the use of information technology are related to changes in the level of corruption. The hypotheses developed in the study show how to use e-government in preventing and fighting corruption. To examine these relationships, the author developed some hypotheses and tested these hypotheses using some empirical models. The developed models confirm the assumptions and demonstrate that increasing the use of e-government will reduce corruption. In our empirical analysis, we first examine the relationship between corruption and e-government in three different years: 2004 (before Vietnam enacted the first law on preventing and fighting corruption in 2005) and 2010 (03 years after Vietnam entry into the WTO) and 2019 (1 year after law on preventing and fighting corruption enacted in 2018). The analysis will be performed on two categories in order to determine whether Vietnam has improved fighting corruption with e-government. Also, after the establishment of models for 2010 and 2019, we explore whether there is a relationship between the change in corruption and e-government in this period of 10 years. The main argument for choosing the study of e-governmentcorruption interrelation is given by the strong development of information technology sector after 2010 and each state citizens' increased involvement in the control of government corruption. The hypotheses which are personal views regarding the relationship between independent and dependent variables based on the literature review are theoretically presented below:

\begin{abstract}
"Vietnam accession lowers corruption by using e-government. It is assumed that the Vietnam accession will increase citizen involvement in solving problems caused by national governments. Thus, due to fulminate development of information technology and the ability to access any information through the Internet, the citizens of Vietnam, also through use of e-government, will initiate a series of actions to control the activity of their governments, which ultimately will lead to a decrease in corruption."
\end{abstract}

\section{Findings and discussion}

\subsection{Vietnam's Laws and Regulations on preventing and fighting corruption via e-government}

Since the 2000s, Vietnam has always paid attention and attached importance to the development of information technology applications in the activities of State agencies, determining that is a driving force contributing to the innovation, creating the ability of short-cut to gain successful industrialization and modernization. In 2014, the Politburo of Vietnam Communist Party issued Resolution No. 36-NQ / TW on accelerating the application and development of information technology to meet the requirements of sustainable development and international integration with the viewpoint "develop information technology in all fields, but with focus on prioritize the application of information technology in administrative management and provision of public services, first of all in the fields related to businesses and people such as education, health, transportation, agriculture ...". A resolution has identified a specific goal by 2020 "to effectively implement the administrative reform program, closely linked with the development of e-Government and the provision of online public services at a high level, and in many sectors". To concretize the Party's policy in 2015, the Government issued the first resolution focusing on e-Government to "Promote the development of e-Government, improve the quality and efficiency of the agencies' activities. State is serving people and businesses better and better. Raising Vietnam's position in e-Government according to the United Nations ranking. Publicize and transparently operate State agencies in the network environment".

Besides the Resolution of the Party, Vietnam National Assembly has enacted the new Law on preventing and fighting corruption in 2018 to replace the Law on preventing and fighting corruption in 2005 . The law in 2018 has many new 
regulations in comparing with the law in 2005. One of the new points is regulation on fighting corruption in the private sector. Moreover, the new law has many regulations of methodology to prevent and fight corruption that apply information technology such as building a system of e-government for 4 levels from Government to Local authority. Law on cybersecurity in 2018 and Penal Code 2015 also have many regulations to govern the use of e-government to reduce corruption status.

Vietnam not only enacted domestic laws and regulations on fighting and preventing corruption, but also join in to become member of international convention against corruption - United Nations Convention against Corruption 2004. This is meaningful activity for Vietnam because it supports the technique and experience of the world for a next period.

\subsection{The status of using E-government in Vietnam}

Construct and complete information infrastructure, create e-government development platform:

Technical infrastructure construction: Over 90\% employees were equipped computer for work; $100 \%$ government agencies have internal network (LAN, Intranet, extranet);

$>$ On a national scale, over $85 \%$ of government agencies are connected to the Government's special data transmission network; Formation and construction national database: with 02 national IT application programs, some national database is initially identified and formed. However, implementation of the projects is still slow.

> Application of IT to serve citizens and enterprises, providing online public services: $100 \%$ government agencies have website/portal. Every year, each agency provides an average of thousands of news. A lot of online public services have been provided on the portal and continue to expand. However, although the number of online public services has been increasing, but most of them are in low level (only allow users to view, download declaration forms). The number of high level online public services used efficiently is confined.

$>$ IT applications in some other areas are quite successful such as tax administration, customs management, population management etc.

\subsection{The status of corruption in Vietnam}

Overall, corruption in Vietnam is characterized by a weak legal infrastructure, financial unpredictability, and conflicting and negative bureaucratic decision-making. Surveys reveal that petty corruption has decreased significantly throughout the country, while high-level corruption has increased. Corruption is considered an obstacle for doing business in Vietnam, and the use of facilitation payments are widespread when dealing with frontline civil servants. Corruption has moved up the political agenda in Vietnam, and the legal framework for tackling corruption is now better developed. Transparency International's 2017 Corruption Perception Index ranks the country 107th place out of 180 countries.

While it has improved over the years since the Doi Moi reforms in 1986, corrupt practices remain evident in the business landscape. Corruption in Vietnam occurs at various levels of government, and even within private organizations. Segon \& Booth noted that at least $30 \%$ of public and civil servants have indicated that they are willing to take a bribe. The work by Segon and Booth was centered on managerial perspectives of expatriate managers who have been working in Vietnam for a few years. Much of the data they gathered from these exchanges revolved around the corrupt practices that were observed within Vietnamese companies and the public sector. 
A survey of businesses in various sectors by Maruichi and Abe showed that companies can expect anywhere between US $\$ 50$ to US $\$ 500$ to obtain required permits, licenses and business registration. Coffey postulates that this corruption erodes the positive consequences of Vietnam's economic growth and development. The Vietnamese Government had implemented an anti-corruption law in 2005 (modified it in 2018), and established the Office of the Central Steering Committee for Anti-Corruption in 2006 as part of their efforts to combat corruption. Martini notes that while the law and legal framework was lauded as one of the best in Asia to combat corruption. It was also reported that the effects of the Anti-Corruption efforts have been limited due to the weak enforcement of laws and lack of information regarding the work of Anti-Corruption agencies. It is observed that these definitions, frameworks and benchmarks are from western or western-sponsored sources and organizations.

The Vietnamese state, through its Anti-Corruption Law passed in 2005 (modified in 2018), defined corruption as "acts committed by persons with positions and/or powers of abusing such positions and/or powers for self-seeking interests". Corrupt acts stated in the law include, but are not limited to, (1) Taking and/or offering bribes, (2) Abusing Powers while performing tasks or duties for self-seeking interests, and (3) Taking advantage of positions to influence people for self-seeking interests. At the societal level, the Vietnamese seem to have a looser definition of corruption. Sato notes that the lay citizen in Vietnam views corruption as a customary practice needed to maintain harmony within the community and support their shared interests. In other words, corruption is seen as a necessary evil to get things done.

A UN Office of Drugs and Crime (UNODC) report of noted Vietnam's partial implementation of the different articles of the convention, such as the toughening of bribery and embezzlement laws. News outlets have also reported about Vietnam stepping up in its Anti-Corruption drive, arresting former high-ranking officials on charges relating to corruption, though critics have indicated that these arrests could be politically motivated.

Despite the progress, from the UNODC report that Vietnam has made various exceptions, such as by not criminalizing bribery in the private sector. This may indicate that while there may be some alignment on certain aspects of corruption with the international actors, the Vietnamese government understands what makes Vietnamese society thrive. It would appear that the Vietnamese citizens understand and view corruption differently. Hence, there exists a mismatch of paradigms that could be one of the sources for the misunderstandings. Neither the Vietnamese nor the international actors have been able to paint an accurate picture on the state of corruption in Vietnam, because what western foreigners may perceive as corruption can be perceived as 'patronage' or clientalism by the local Vietnamese, which Sato mentioned is part of their culture. This mismatch is exacerbated by rankings such as the Corruption Perceptions Index. This Index, founded and managed by Transparency International, is one that many around the world use as the basis for their academic or professional work. It is supported by various western countries and western-based international Non-Profits and organizations, who also serve as the donors to Transparency International. While popular among scholars, the Index itself does have some limitations. One of them is that the definitions, benchmarks and methods employed by the Corruption Perceptions Index is based on western perspectives and values, which may have a varied perspective on the issue of corruption, its causes and consequences compared to other non-western nations it assesses. Another limitation is the Index only looks at public sector corruption, thus does not paint a comprehensive picture of a country's corruption due to the absence of data from other sectors. Finally, the index itself is based on 'perceptions' of corruption.

As there is no universally accepted definition, understanding or measurement of corruption, it is therefore difficult to prescribe how corrupt a country is. Not all countries in the world, such as Vietnam, subscribe to the Transparency International definition or benchmark for corruption, although its arbitrary definition and benchmark overlaps with the Transparency International in some areas.

In 2011, 44\% of Vietnamese have reportedly paid a bribe, commonly as a form of 'grease money' to expedite or fulfill basic tasks or services. Bribery can also be found in the higher education sector. McCornac mentioned that corrupt practices are the norm in Vietnamese higher education, citing the low salary of teachers as a key reason why 
the practice of bribing to gain entry into educational institutions and to cheat in the examinations became commonplace. He also stated that the bribes were not only monetary, but also come in the form of expensive gifts such as phones and expensive bags. Anh Nguyen \& Tran-am determined through their study that corruption hampers economic growth, though they have noted in the same study that corruption is positively correlated to human capital, which is also positively correlated to economic growth. Up to this point, Coffey, Anh Nguyen \& Tran-am and McCornac have clearly illustrated that corruption brings about negative effects to the country's economy and is detrimental to the nation's education sector. The study by Anh, Nguyen \& Tran-am was sponsored by the UK Department for International Development and was presented at the 2014 Vietnam Economists Annual Meeting to foreign economists, scholars and students. The authors were also western educated in the area of economics, which suggests that the study was based on a western economics perspective of corruption, consistent with earlier definitions by Transparency International. McCornac was also similarly educated in Economics and thus, his study was also based on an economics perspective. McCornac has previously taught in Vietnamese universities for about 10 years and in a related study published in 2008, he conducted informal surveys and interviews with undergraduate students, faculty members and university administrators, many of whom shared instances where they personally observed situations of corruption in the form of gift-giving and aiding to cheat.

There are, however, scholars who think otherwise. Leff stated that bribery is needed in the developing world to reduce rigidities that inhibit investments and economic growth. Corruption, or more specifically bribes in this case, would help companies reduce the amount of uncertainty because bribes enable the companies to control and dictate the actions of government officials they deal with. Though Leff's work is dated, he basically provided a reason why 'grease money' is needed in Vietnam, in response to Coffey. In a more recent study, Lui argued that paying bribes could allow customers to achieve 'social optimal equilibrium', where after factoring in other associated costs such as waiting, it may be more cost-effective to pay the bribe and allow the company to continue its profit-generating work.

Lui and Leff's main argument is that bribes help move things along, especially if the institutions of the state are corrupt or unable to police itself. While their arguments seem logical, I find them too simplistic because they do not take into account the intentionality of the officials being bribed, as they can decide the bribe amount arbitrarily or even add on more obstacles to extract additional payment. Hence, there is no sustained reduction of uncertainty for businesses, who could continuously need to pay bribes of varying amounts which could lead to higher operating costs and less competitiveness. On McCornac's article regarding corruption in the higher education sector, his account of teachers accepting bribes in exchange for helping students cheat is clearly a negative case of corruption. The practice of 'bribing 'or paying your way for admission into university is not a phenomenon unique to Vietnam. As an Associate Professor in a community college based in the US, he would have been aware that within the US itself, there is a longstanding practice of 'paying for a place in US universities' through donations as soon as or even before the student was admitted. This practice is usually only done by affluent families, which seems to mirror what McCornac mentioned about buying university admission in Vietnam. While it can be argued that donations go to the university while bribes go to the individual, the effects of this practice are the same, less qualified candidates gain entry while more qualified students may be deprived of admission.

In Vietnam, business transactions may not only take place within the confines of the office. Much of these can spillover after hours, where businessmen may host their prospective clients for social activities or 'business drinking', which is aimed at cajoling them into finalizing a business deal. These activities usually involve drinking at nightspots, where Kimberly Kay Hoang noted that a substantial number of business deals in Vietnam which contributed to its economy have been facilitated through such drinking sessions.

\subsection{The impact of E-Government of Vietnam on preventing and fighting the corruption}

Commenting on the current situation of corruption and fighting against corruption in Vietnam, the 3rd Resolution of the 10th Party Central Committee affirms: "Over the years, especially since the 6th Central Conference, the Party and State have strengthened the fight against corruption, waste and achieved certain results, contributing to socio- 
economic development, maintaining political security and social order and safety. Many cadres of the Party members maintain the revolutionary morality, where to go in this struggle. Many corruption cases, including large and complex cases with many serious consequences, have been discovered and handled. However, the fight against corruption and waste still has many limitations, shortcomings and low efficiency. Corruption and waste are still serious in many branches, levels, and fields with a wide scope, complicated nature, causing bad consequences in many ways, reducing people's confidence, is one of the great threats threaten the survival of the Party and our regime". Thus, the Communist Party of Vietnam has clearly affirmed:

- Corruption is an existing social phenomenon in Vietnam.

- The level of corruption is serious.

- Wide range of corruption, complex nature of corrupt acts.

- The consequences of corruption are harmful in many ways, possibly leading to the danger of threatening the survival of the socialist regime in Vietnam.

However, as former State President of Vietnam, Mr. Nguyen Minh Triet said in the 2007 Online Dialogue with Youth, corruption is everywhere, not only Vietnam and Vietnam are not the countries with the most serious corruption. According to Transparency International's Corruption Rankings, Vietnam's corruption index for 2010 was 2.7 out of 10 (which is a reflection of high levels of corruption), but compared to other countries such as Russia, Myanmar, Somalia, the corruption index of these countries is much higher.

The important issue is, it is necessary to objectively and substantially assess the current corruption situation in Vietnam. Furthermore, it must be quantified as specific as possible, using specific data to have appropriate prevention measures. These data, first of all, are gathered by agencies with anti-corruption functions, especially those produced by specialized agencies. These agencies are the Anti-Corruption Bureau of the Government Inspectorate, the Corruption Crime Investigation Department under the General Department of Crime Investigation Police - Ministry of Public Security and the Department of Prosecution and Investigation. Corruption belongs to the Supreme People's Procuracy.

According to the Government Inspectorate's data, in for 04 years (from 2007 to 2010), the entire inspection sector has deployed 53,954 inspections, recommending disciplinary action for 1300 collectives, 11,022 individuals with and transferred to investigation agency to handle 439 cases.

According to the Supreme People's Prosecutors, the results of handling corruption cases in 4 years nationwide (20082010) are:

- In 2007: prosecuted 427 cases, 960 defendants; prosecuted 391 cases, 1030 defendants; trial of 350 cases, 843 defendants.

- 2008: prosecuted 282 cases, 622 accused; prosecuted 394 cases, 914 defendants; 36 cases trial, 785 defendants.

- 2009: prosecuted 289 cases, 631 defendants; prosecuted 321 cases, 819 defendants; Trial of 308 cases, 718 defendants.

- In the first 9 months of 2010, there were 188 prosecution cases and 3373 defendants prosecuted; prosecuted 253 cases, 631 defendants, tried first-instance 211 cases, 479 defendants.

The "Corruption Perceptions Index" by Transparency International for the public sector showed 37/100 points in Vietnam for 2019. The scale has a range from 0 to 100, in which corruption raises, the higher the number is. With this result, Vietnam ranks 96th. So, compared to other countries it is slightly below average. Compared to the previous year, in 2019 the level of corruption decreased a bit. In the long term, it has also declined moderately in recent years. The Corruption Perceptions Index ranks countries and territories based on how corrupt their public sector is perceived to be. A country or territory's rank indicates its position relative to the other countries and territories in the index.

On that basis, the Vietnamese ministries, and localities have made many efforts and achieved important initial results as a foundation for e-Government development. The legal corridor in information technology application and e- 
Government development has been gradually established. Databases have information background nature such as National Business Registration Database, National Insurance Database, National Population Database, Database National land is being built and all components are put into operation. State agencies have provided a number of essential online public services for businesses and people such as enterprise registration, tax declaration, tax payment, electronic customs, social insurance, etc. Some ministries have handled work records in the network environment. In some localities, the electronic single - window information system has been put into operation, gradually improving the transparency and responsibility of the public services. The quality of human resources in information technology in Vietnam has also been paid attention.

However, the overview can be seen that the implementation of e-Government has not been achieved as expected by the leaders of the Party and Government. Vietnam's position in the United Nations E-Government Development Index is still at average, according to the latest United Nations report, in the past 2 years, we have increased by 1 rank, ranked 88 out of 193 countries and territories were assessed. In the ASEAN region, Vietnam is ranked modestly at the 6th position. The results of implementing many tasks on e-Government are still very slow and in many places the implementation is formal. The construction and deployment of national databases, information technology infrastructure as a foundation for e-Government development is very slow compared to the required progress; data information systems are still local, have no connection or share data between information systems; data quality and information have not been updated in a timely and accurate manner. Many implemented information systems have not ensured safety and information security, and the level of national reliability in electronic transactions is low. The provision of public services online is still run by quantity, while the rate of implementing public services online is still very low; the handling of administrative procedures and the handling of work documents are still heavily manual and paper. There are still barriers in the investment mechanism of information technology application, making it difficult for businesses to implement projects. This leads to the situation that many leaders of the Government, ministries, branches and localities do not have enough information on digital data of their subjects.

\section{Conclusion}

From all of the analysis above, we can conclude that to end corruption, we must promote transparency, accountability and integrity at all levels and across all sectors of society. In order to continue to inherit and promote the achievements, to meet the goals and requirements of the Government and the Prime Minister in the next period, overcoming existing limitations, step by step realizing the determination. Building a Government to create, develop, integrity, act, serve people and businesses, especially in the context of the industrial revolution 4th. In the next period, Vietnam needs to perfect the foundation for the development of the power government towards the digital economy and digital society, and improve the capacity and efficiency of the Government apparatus organization. At the same time, it is necessary to ensure safety, information security and cybersecurity and continue to raise Vietnam's position in the United Nations' e-Government ranking as well as contribute to the increase in competition indexes and national development index.

\section{Recommendation of solutions}

\subsection{Accelerating the development and completion of institutions to create a complete and comprehensive legal basis for the development of e-Government}

According to the experience of developed e-Government countries, the institutional foundation of e-Government must be ahead, while Vietnam still lack many regulations and policies. Therefore, Vietnam's Government must enact Decrees on data sharing; on personal data protection; electronic authentication and privacy protection; on reporting regime among State administrative agencies, etc. In the next period, it is necessary to study and propose the development of a Law on e-Government and guiding documents to ensure the legal corridor for e-Government development based on open data and application of new technologies towards the background digital economy, digital society. 


\subsection{Complete basic national databases}

In parallel with the building of institutions, it is necessary to focus on completing the construction of national fundamental databases, especially the national database on population, land, etc. To ensure effective the use of these national databases needs to build a platform for data integration and sharing between central and local information systems; the interconnection system sends and receives electronic documents; electronic identity authentication system; linkage between the government's specialized digital signature authentication systems and public digital signatures; National payment gateway, etc. to ensure that data and information are uninterrupted among all levels of Government.

\subsection{Setting up systems of public services and the government's administration}

Accordingly, the Government Office, ministries and local authorities are actively building a National Public Service Portal and deploying an electronic single - window information system. This is an important system to connect the Government with people and businesses, demonstrating the servant spirit of the Government. The national public service portal should aim to be a coherent, complete and friendly digital presence of the Government serving people and businesses.

In order to serve the management and administration of the Government, in the next period, Vietnam will build a paperless Government Information Systems; Electronic system of policy consultation; The national reporting information system towards the construction of the Steering and Operation Center of the Government and the Prime Minister has been focused on research and establishment.

\subsection{Review, rearrange and mobilize all financial and human resources}

In recent years, the Vietnam Government has made certain investments in the implementation of information technology applications. However, investment projects are still fragmented and have not created a fundamental change to build e-Government. In the coming time, in order to improve investment efficiency, it is necessary to review, rearrange and mobilize resources to implement the tasks of prioritizing e-Government development, and adjust the specific investment mechanism for the public information technology, increasing socialization to bring into full implementation public - private cooperation in this work. At the same time, it is necessary to organize training, education, exploitation and use of information systems, use of online public services at level 3 and 4 for people, businesses and research and develop incentive mechanisms attract talents to participate in building and developing eGovernment.

Vietnam also needs to improve communication efficiency, awareness of e-government, digital economy, digital infrastructure through the implementation of communication programs to raise awareness of changing behavioral habits, creating the consensus of all parties on e-Government development.

\subsection{Promote the role of the leader, improve enforcement efficiency and accountability}

Showing his determination to build an e-Government, the Prime Minister has directed the establishment of the National Committee on e-Government on the basis of consolidating the National Committee on Information Technology Application by the Prime Minister is the Chairman of the Committee. The Committee members are Ministers who are directly involved in the tasks of building e-Government to connect across ministries and localities in performing the tasks. At the same time, the Committee has the participation of representatives of the private sector to promote the efficiency of public - private cooperation in implementing this task. E-Government implementation tasks will be assessed associated with the individual responsibility of the heads of each ministry and locality and measured through a set of indicators to evaluate the efficiency and measure the quality of construction results. EGovernment development ensures accuracy and fairness through the Committee's Working Group. Building an e- 
Government towards a digital government and a digital economy is a major policy that should be promoted in Vietnam in the next period.

\section{References}

Andersen, T. B., Rand, J., 2006. Does e-Government Reduce Corruption? University of. Copenhagen, Department of Economics, Working Paper Anderson, T. B., 2009. E-government as an anti-corruption strategy. Information Economics and Policy, 21, 201-210.

Bertot, J., Jaeger, P., Grimes, J., 2010. Using ICT to create a culture of transparency: E-Government and social media as openness and anticorruption tools for societies, Government Information Quarterly, vol.27: 264-271.

Bhatnagar, S., 2003. E-government and access to information. Global Corruption Report 2003. Washington DC: Transparency International.Basyal, D.K., Poudyal, N. and Seo, J.-W. (2018), "Does E-government reduce corruption? Evidence from a heterogeneous panel data model", Transforming Government: People, Process and Policy, Vol. 12 No. 2, pp. 134-154. https://doi.org/10.1108/TG-12-2017-0073

Cullier, D. and Piotrowski, S. J., 2009. Internet information-seeking and its relation to support for access to government records. Government Information Quarterly, 26, 441-449.

Do Lap Hien (2017), "E-Government Policy of Vietnam", 3rd Asia-Pacific Regional Forums on Smart Cities and eGovernment

Eunhee Lee (2017): The Impact of E-government on Corruption Control, Spring Martin School of Public Policy \& Administration Graduate Capstone

Ganuza, J. J., Hauk, E., 2004. Economic integration and corruption. International Journal of Industrial Organization, 22(10), 1463-1484.

Mistry, J. J., Jalal, A., 2012. An empirical analysis of the relationship between e-government and corruption. The International journal of digital accounting research, 12(18), 145-176.

Mistry, J.J., 2012. The Role of e-Governance in mitigating corruption, Accounting and the Public Interest, vol.12, n.1: 137-159.

Mulgan, R., 2007. Truth in government and the politicization of public service advice. Public Administration, 85, 569-586.

Relly, J. E., Sabharwal, M., 2009. Perceptions of transparency of government policymaking: A cross-national study. Government Information Quarterly, 26, 148-157.

Sandholtz, W., Gray, M. M., 2003. International integration and national corruption. International Organization, 761800.

Vietnam Government (2009), Decree No 102/2009/ND-CP on investment management of IT applications and Guidance circulars.

Vietnam Government (2011), Decree No 43/2011/ND-CP on providing information and online public services on the portal/website of government agencies, through this, the online public services are divided into 4 levels from low to high level to inspection and assessment 
Pham | Quantitative Economics and Management Studies (QEMS), 2020, 1(5): 335-345

\section{Regulation and Law documents}

United Nations (2004), Convention against Corruption

Vietnam's Politburo (2014), Resolution No. 36-NQ / TW

National Assembly of Vietnam (2018), Law on prevent and fight corruption

National Assembly of Vietnam (2015), Penal Code

National Assembly of Vietnam (2015), Law on Cybersecurity

\section{Webpage on a Website References}

https://www.transparency.org/en/countries/vietnam

http://egov.chinhphu.vn

https://dichvucong.gov.vn/p/home/dvc-trang-chu.html

https://dangkykinhdoanh.gov.vn/en/Pages/default.aspx

https://data.gov.vn/?fbclid=IwAR1KPmhSnY4Dj-R6pPCdazMUp1oO7D_H4I8sCrgQKOFqj9_Wu1y4gc-s0mA

http://www.gdla.gov.vn/ 